CZASOPISMO INŻYNIERII LA¿DOWEJ, ŚRODOWISKA I ARCHITEKTURY JOURNAL OF CIVIL ENGINEERING, ENVIRONMENT AND ARCHITECTURE

JCEEA, t. XXXIII, z. 63 (4/16), październik-grudzień 2016, s. 407-418

Janusz PEŁCZYŃSKI ${ }^{1}$

Bartłomiej TOMKOWICZ

\title{
ZAGADNIENIA ETAPU PROJEKTOWANIA ZMIANY SPOSOBU UŻYTKOWANIA STRYCHÓW KAMIENIC NA WYBRANYCH PRZYKŁADACH W STREFIE ŚRÓDMIEJSKIEJ RZESZOWA
}

\begin{abstract}
Jednym ze sposobów pozyskiwania powierzchni użytkowych w centrach miast jest adaptacja strychów kamienic. Zainteresowanie wzbudza możliwość wytworzenia mieszkań o niepowtarzalnym, indywidualnym charakterze przy stosunkowo niskich nakładach finansowych. Adaptację strychów w strefie śródmiejskiej można traktować także jako działanie $\mathrm{w}$ ramach zrównoważonego rozwoju w kierunku przekształceniowym, przeciwstawiającym się trendowi rozlewania się miast (urban sprawl). Liczne korzyści płynące z takiego działania pojawiają się zarówno w skali budynku jak i miasta. W praktyce, proces pozyskania i przekształcenia strychu na mieszkanie może okazać się długotrwały, a przede wszystkim złożony tak na płaszczyźnie formalnej jak i projektowej. Występujące uwarunkowania projektowe można podzielić na kilka zasadniczych grup obejmujących: stan techniczny budynku, uwarunkowania formalno-prawne, uwarunkowania architektoniczne, konstrukcyjne i instalacyjne. Pełne rozpoznanie istniejących uwarunkowań w ramach analizy przedprojektowej jest niezbędną podstawą optymalnego wyznaczenia założeń adaptacji. W artykule omówiono zagadnienia uwarunkowań projektowych na tle trzech przykładów adaptacji czterokondygnacyjnych kamienic w Rzeszowie, różniących się pod względem wymagań konserwatorskich: kamienicy przy ul. Kraszewskiego 1 leżącą w strefie ochrony konserwatorskiej, kamienicy przy pl. Śreniawitów 2 wpisaną do ewidencji zabytków i kamienicy przy ul. Grodzisko 3 wpisaną do rejestru zabytków. Podjęto kwestię ogólnych uwarunkowań projektowych związanych ze zmianą sposobu użytkowania, przedstawione zostały przyjęte założenia i rozwiązania adaptacji omawianych strychów w zakresie układów funkcjonalnych, stropów, więźby dachowej.
\end{abstract}

Słowa kluczowe: adaptacja, przebudowa, zmiana funkcji, uwarunkowania projektowe adaptacji

\footnotetext{
${ }^{1}$ Autor do korespondencji / corresponding author: Janusz Pełczyński, Politechnika Rzeszowska, Zakład Urbanistyki i Architektury, Al. Powstańców Warszawy 12, 35-959 Rzeszów; tel.: 17865 1691; jpe@ prz.edu.pl

2 Bartłomiej Tomkowicz, Creativa Studio Architektury i Budownictwa, ul. T. Lenartowicza 27/4, 35-051 Rzeszów; tel.: 604756 888; biuro.creativa@gmail.com
} 


\section{Wprowadzenie}

Zmiana sposobu użytkowania strychu kamienicy w strefie śródmiejskiej jest zadaniem złożonym, o specyficznym charakterze. Występujące uwarunkowania można podzielić na kilka zasadniczych grup obejmujących: stan techniczny budynku, uwarunkowania formalno-prawne oraz uwarunkowania projektowe architektoniczne, konstrukcyjne i instalacyjne. Pełne rozpoznanie istniejących uwarunkowań w ramach analizy przedprojektowej jest niezbędną podstawą optymalnego wyznaczenia założeń adaptacji.

W niniejszym artykule przedstawiona została problematyka fazy projektowej związanej z adaptacjami strychów kamienic przy ul. Kraszewskiego 1, pl. Śreniawitów 2 i ul. Grodzisko 3 w Rzeszowie. Bliższy opis obiektów wraz z omówieniem występujących uwarunkowań formalno-prawnych zawarty został w artykule [1].

\section{Ogólnie uwarunkowania projektowe adaptacji strychów}

Ogólnie uwarunkowania projektowe dla adaptacji strychów tworzą:

- istniejący układ konstrukcyjny, funkcjonalny, instalacyjny, układ i kompozycja elewacji kamienicy,

- nośność istniejących elementów konstrukcyjnych budynku: fundamentów, ścian, stropów, więźby,

- zakres formalnie dopuszczanej ingerencji w strukturę i geometrię budynku,

- wymogi zachowania oryginalnych elementów konstrukcyjnych i wykończeniowych [2].

Zazwyczaj najbardziej oczekiwanym w ramach zmiany sposobu użytkowania strychu na cele mieszkalne jest podejście polegające na jak najmniejszej interwencji. Wynika to przede wszystkim z niższych kosztów inwestycyjnych a także z urzędowej ostrożności służb konserwatorskich i organów administracji architektonicznej, które w drodze warunków i decyzji często ograniczają dopuszczalny zakres interwencji do minimum. Do rzadkich należą sytuacje, gdy zezwala się na nadbudowę obiektów historycznych czy to w postaci podniesienia czy zmiany formy dachu. Najczęściej preferowaną formą działania jest nieinwazyjne wprowadzenie lukarn lub okien połaciowych oraz ewentualne korekty konstrukcji wewnętrznej.

Specyfiką projektowania $\mathrm{w}$ przestrzeni strychów jest także konieczność spełnienia wszystkich wymagań obecnych warunków technicznych. Wymaganie to dotyczy nie tylko obszaru bezpośrednio objętego projektowaniem, ale również pozostałych części budynku leżących poza bezpośrednim obszarem adaptacji a mające związek z funkcjonowaniem adaptowanej powierzchni. Biorąc pod uwagę że w zabudowie pierzejowej budynek uznaje się za odrębny w przypadku oddzielenia go od innych części zabudowy ścianami oddzielenia pożarowego od 
fundamentów pod dach, zakres analizy np. odnośnie zagadnień ochrony i odporności pożarowej może być niezwykle poszerzony [3].

Główne problemy projektowe odnoszące się bezpośrednio do przestrzeni adaptowanego strychu sprowadzają się do możliwości prawidłowego rozwiązania zakładanej funkcji wraz z jej konstrukcją i częścią instalacyjną, przy wprowadzeniu akceptowalnych zmian elewacji budynku i jego gabarytu.

Jako pierwsze zagadnienie projektowe można wymienić wysokość przestrzeni strychu: czy i na ile umożliwia wprowadzenie przewidywanej funkcji. Ocenę należy dokonać $\mathrm{z}$ uwzględnieniem koniecznych korekt istniejącej konstrukcji i przegród [4].

Drugim charakterystycznym zagadnieniem w przestrzeni strychu jest występowanie kominów oraz ograniczeń przestrzeni przez elementy więźby.

Określone uwarunkowania projektowe tworzy także możliwość wprowadzania okien i przeszkleń w celu zapewnienia naturalnego oświetlenia wnętrz; jest ona zazwyczaj ograniczona od strony elewacji frontowej przez konserwatora zabytków, który w obiektach objętych ochroną bronić będzie spójności charakteru kamienicy i dominacji jego historycznej kreacji.

Następnie, istotna z punktu widzenia przyjmowania rozwiązań instalacyjnych, ale także układu funkcji, jest lokalizacja pionów instalacji, w tym przede wszystkim pionów kanalizacji sanitarnej.

Poruszanie się w sztywno określonej przestrzeni z jednej strony ogranicza wachlarz możliwości do kilku rozwiązań, z drugiej zaś zmusza do przyjmowania rozwiązań kompromisowych; uzyskanie rozwiązania bez jakichkolwiek kompromisów nie jest proste, a w szeregu przypadków w ogóle niemożliwe [5], lub związane z nadmiernymi kosztami inwestycyjnymi.

\section{Założenia projektowe i przyjęte rozwiązania.}

\subsection{Układy funkcjonalne}

W omawianych przypadkach adaptacji strychów dążono do uzyskania optymalnych układów funkcjonalnych uwzględniających spełnienie założeń w zakresie ilości lokali i ich programu użytkowego. Starano się zachować w maksymalnym stopniu zasady projektowania funkcji mieszkaniowej - podział na strefę dzienną i nocną, zapewnienie doświetlenia naturalnego w odpowiedniej ilości, prawidłowy rozkład pomieszczeń ich proporcje.

W przypadku strychu w budynku przy ul. Grodzisko 3 założeniem było wytworzenie dwóch lokali mieszkalnych o określonym programie funkcjonalnopowierzchniowym (Rys. 1). Większe mieszkanie wielkości ok. $120 \mathrm{~m}^{2}$ powinno mieć duży pokój dzienny z otwartym aneksem kuchennym i przestronnym balkonem, gabinet, dwie sypialnie i dwie łazienki. Mieszkanie mniejsze wielkości ok. $60 \mathrm{~m}^{2}$ o elastycznym układzie dającym możliwość dzielenia i otwierania przestrzeni w zależności od potrzeb. 
Podział przestrzeni na lokale wyniknął z rozmieszczenia ścian nośnych i kominowych. Lokalizacja klatki schodowej warunkującej dostępność do przestrzeni przeznaczonej do adaptacji pozwoliła tylko w jednym z mieszkań uzyskać układ na przestrzał (północno-południowy). Mniejsze mieszkanie o orientacji wyłącznie północnej ze względu na obowiązujące przepisy dotyczące oświetlenia naturalnego zaprojektowano jako jednopokojowe. Wejścia do obydwu lokali dostępne są bezpośrednio z klatki schodowej. W obydwu mieszkaniach zrealizowano strefowanie funkcji i założenia programowe. W dużym mieszkaniu układ kominów i instalacji wygenerował komunikację w postaci długiego korytarza. Inne analizowane warianty układów, choć umożliwiały zlokalizowanie strefy dziennej bliżej wejścia, w opinii projektantów były mniej korzystne. Ostatecznie uzyskano klarowny rozkład rzutu o dogodnych dla aranżacji proporcjach przestrzeni.

Nie zawsze jest to do osiągnięcia na strychach zwłaszcza wówczas gdy powierzchnie przeznaczone do aranżacji nie tworzą zwartego, regularnego kształtu. Taką sytuację napotkano przy adaptacji Kraszewskiego 1, gdzie na powierzchni ok. $100 \mathrm{~m}^{2}$ założono wytworzenie 2 mieszkań z opcją przyszłego ich połączenia (Rys. 2). Utrudnieniem był tu układ kominów, konstrukcja więźby, lokalizacja pionów sanitarnych oraz kształt rzutu związany z wcześniej wyodrębnionymi do osobnego zagospodarowania obszarami. Lokalizację łazienek w obydwu mieszkaniach uznać należy za kompromis wymuszony uwarunkowaniami tego strychu. Wejścia do mieszkań zdecydowano usytuować przy północnej klatce schodowej.

W przypadku adaptacji strychu przy Pl. Śreniawitów 2 zakładano wytworzenie 6 niezależnych lokali mieszkalnych o różnorodnym metrażu i programie użytkowym (Rys. 3). Zasadnicze okazały się uwarunkowania uzyskane w drodze rozmów z konserwatorem i przedstawionych mu koncepcji. Umożliwienie rozbudowy w pionie centralnej klatki schodowej stanowiło o sensowności inwestycji. Istotnym ze względów funkcjonalnych $\mathrm{w}$ rozmowach $\mathrm{z}$ konserwatorem było uzyskanie zgody na wstawienie lukarn w przestrzeń adaptowanego strychu. Ich rozstaw powiązany został z układem okien na kondygnacjach poniższych. Nadto dopuszczone zostało zastosowanie okien połaciowych oraz niezbędna nadbudowa dachu od strony podwórza.

Pozostałe uwarunkowania projektowe związane były, podobnie jak w pozostałych przypadkach, z gabarytem strychu, jego układem konstrukcyjnym, kominowym i instalacyjnym.

W efekcie prac wykreowano mieszkania jedno, dwu i trzypokojowe $\mathrm{z}$ aneksami kuchennymi. W części mieszkań udało się wytworzyć także garderoby. Kształt samych mieszkań uzależniony został od linii kominów przebiegającej w środkowej części budynku w obydwu jego skrzydłach oraz przylegającej do niej komunikacji. Nienormatywną drewnianą klatkę schodową w zachodniej części, którą dotychczas można się było dostać na strych z poziomu drugiego piętra wyłączono z opracowania. 

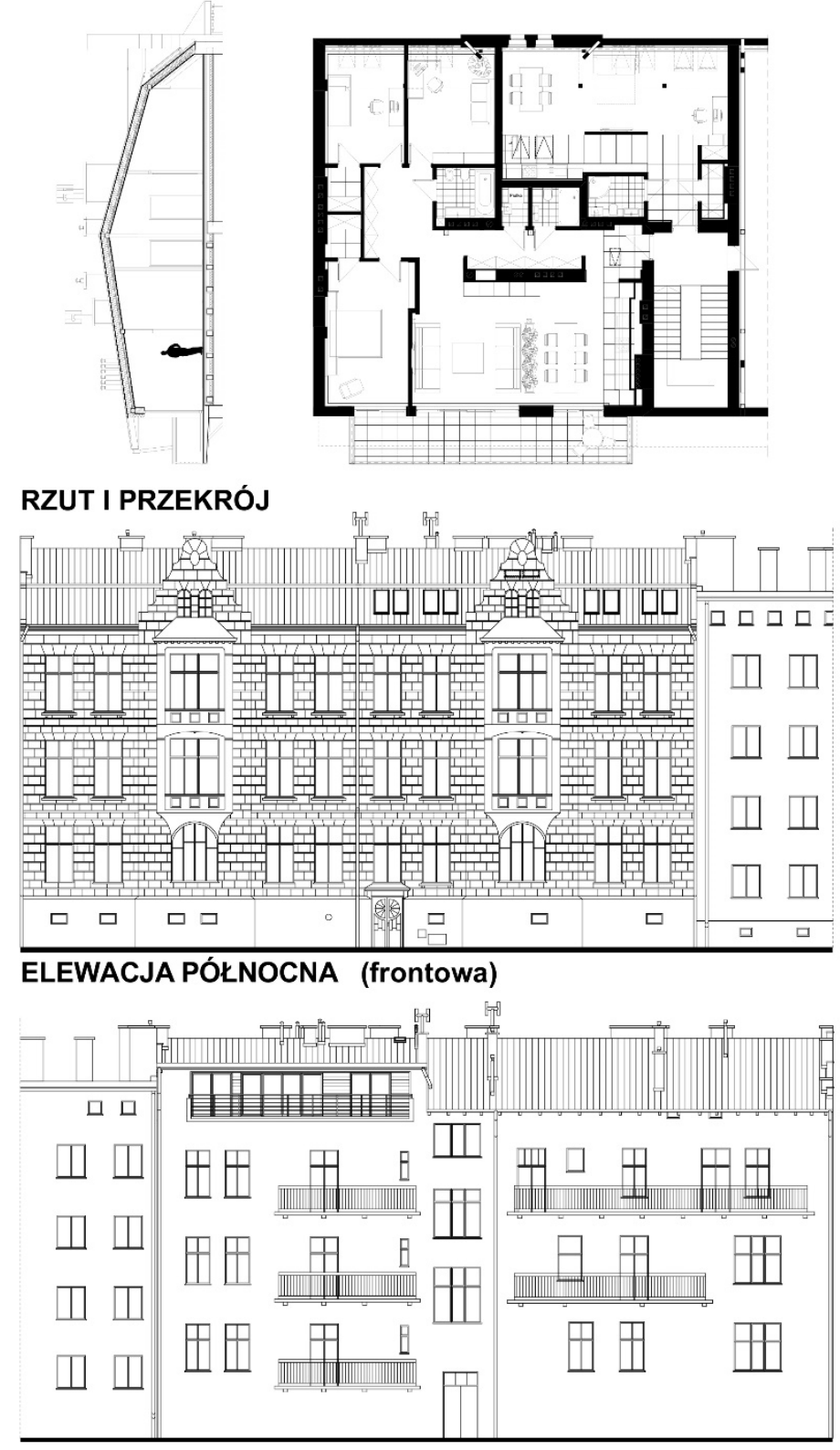

ELEWACJA POŁUDNIOWA (od podwórza)

Rys. 1. Kamienica przy ul. Grodzisko 3, stan projektowany - rzut i przekrój strychu, elewacje północna i południowa

Fig. 1. The building at 3 Grodzisko Street, state designed- floor plan and crosssection of the loft, front and back elevation 

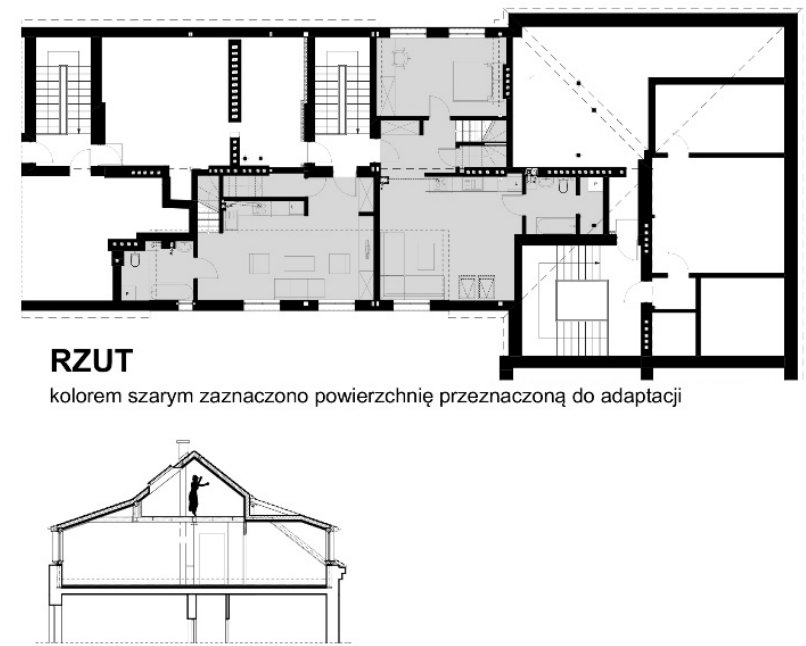

PRZEKRÓJ

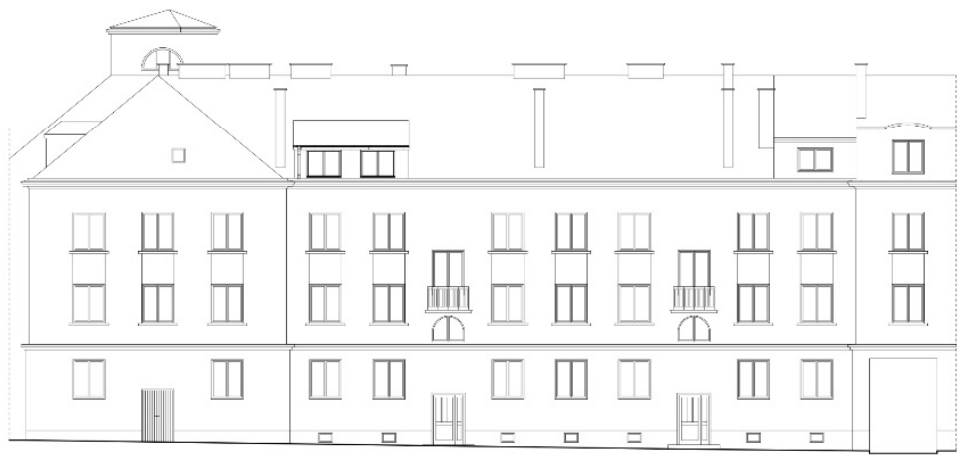

ELEWACJA PÓŁNOCNA (frontowa)

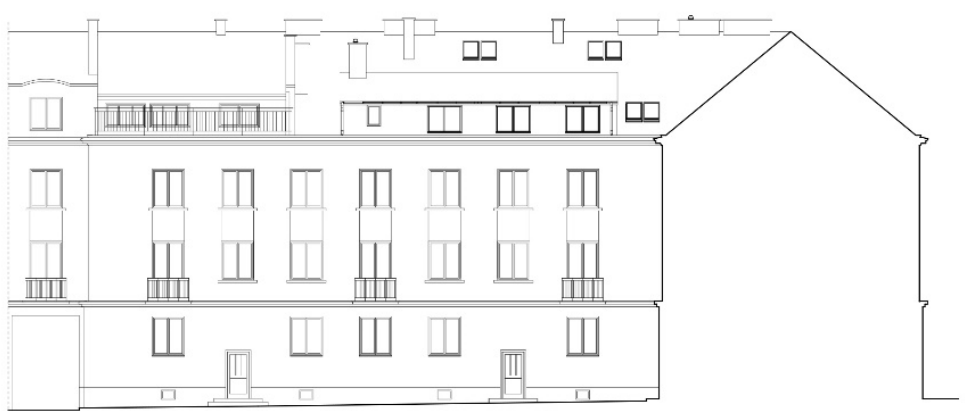

ELEWACJA POKUDNIOWA (od podwórza)

Rys. 2. Kamienica przy ul. Kraszewskiego 1, stan projektowany - rzut i przekroje strychu, elewacje frontowa i od podwórza

Fig. 2. The building at 1 Kraszewskiego Street, state designed - floor plan and crosssections of the loft, front and back elevation 


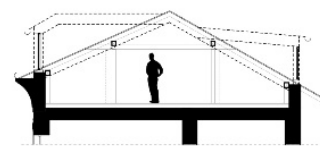

PRZEKRÓJ
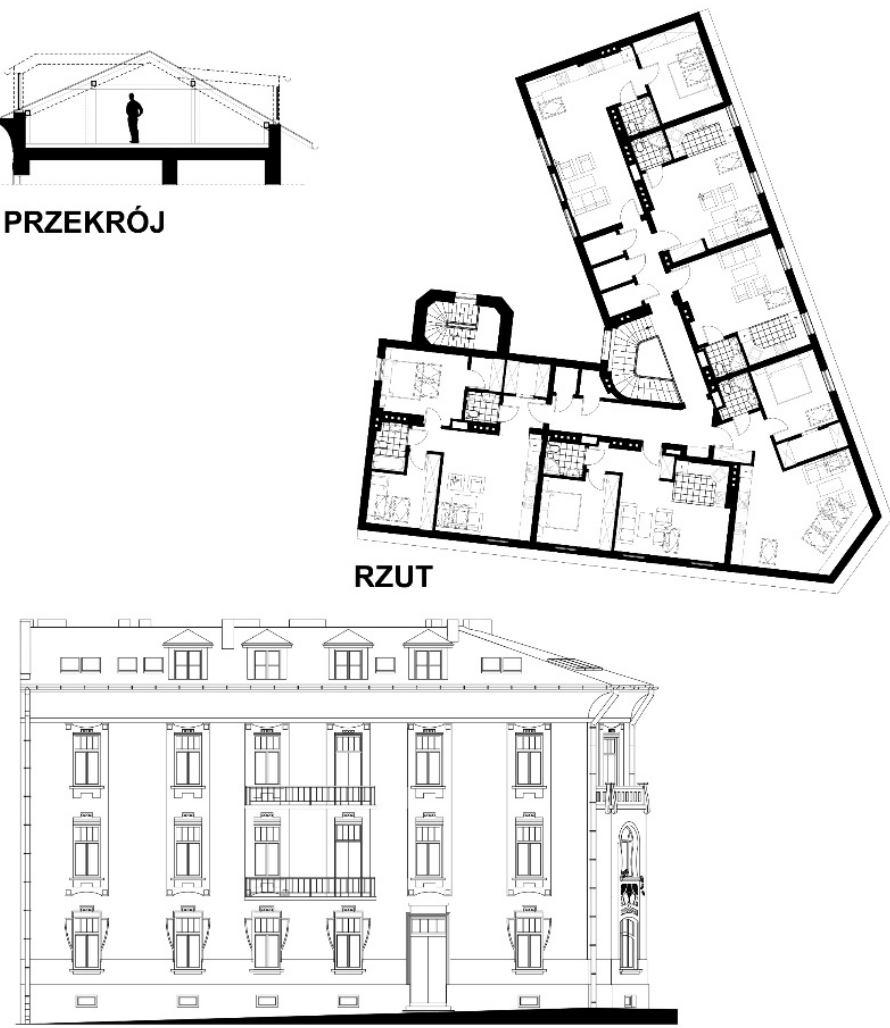

ELEWACJA POŁUDNIOWA

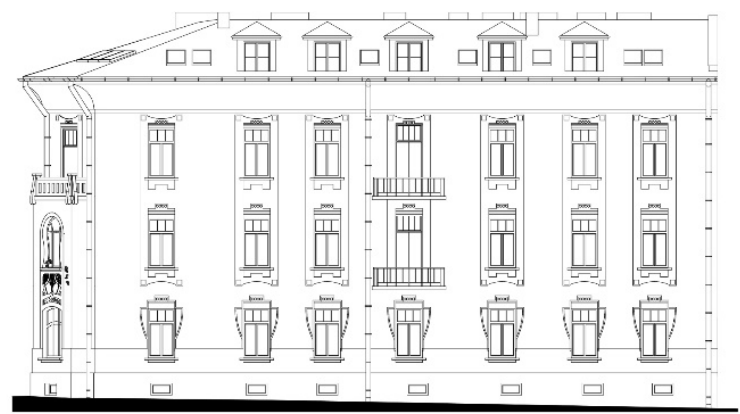

\section{ELEWACJA WSCHODNIA}

Rys. 3. Kamienica przy pl. Śreniawitów 2, stan projektowany - rzut i przekrój strychu, elewacje południowa i wschodnia

Fig. 3. The building at 2 Śreniawitów Square, state designed - floor plan and cross-section of the loft, south and east elevation 


\subsection{Stropy}

Ze względów konstrukcyjnych na szczególną uwagę podczas analizy i projektowania zasługuje układ statyczno-materiałowy stropu. Możliwość wykorzystania istniejącego stropu jest najlepszym rozwiązaniem, jednak w praktyce nie zdarza się to często.

Strop dla funkcji mieszkalnej wg normy EN 1991-1-1:2002 powinien przenosić obciążenia rzędu 1,5-2,0 $\mathrm{kN} / \mathrm{m}^{2}$. Większość kamienic, zwłaszcza tych wznoszonych pod koniec XIX i na początku XX wieku posiada stropy drewniane, których właściwości mechaniczne w przestrzeniach użytkowych są rzędu $1,2 \mathrm{kN} / \mathrm{m}^{2}$ a dla strychów $0,5 \mathrm{kN} / \mathrm{m}^{2}$ [6], co oznacza potrzebę ich wzmocnienia, wymiany, lub wprowadzenia nowej, niezależnej konstrukcji.

Najbardziej złożone zagadnienie stropu napotkano w kamienicy Grodzisko 3. Strop belkowy w poziomie strychu w części północnej - frontowej posiada niemal 7-metrową rozpiętość bez podpór pośrednich. W części południowej ze względu na zagęszczenie ścian nośnych niższych kondygnacji długość elementów drewnianych jest mniejsza, ale podłużny wzglądem kalenicy układ belek wraz z przyjętym na wstępie założeniem wykonania długiego balkonu w tej części, znacznie skomplikowały dobór rozwiązania projektowego. Rozważono wprowadzenie alternatywnych rozwiązań dla przystosowania stropu dla celów mieszkalnych. Analizowano możliwość zastosowania stropów lekkich drewnianych, drewniano-stalowych lub stalowych w rozwiązaniach nie wymagających użycia dźwigu ani rozbiórki dachu na czas montażu, stropów prefabrykowanych z płyt strunobetonowych (SMART) i kanałowych, a także wylewanych gęstożebrowych (RECTOR) i monolitycznych niezależnych od stropu istniejącego jak i z nim powiązanych. Ostatecznie do realizacji wybrano strop żelbetowy z wykorzystaniem istniejącego stropu drewnianego wcześniej wyremontowanego i wzmocnionego nadbitymi elementami drewnianymi. Płyta żelbetowa nie została zespolona ze stropem drewnianym, ale przy jej projektowaniu korzystano z zasad konstruowania stropów zespolonych [7]. Osiągnięto cel w postaci znaczącej poprawy właściwości mechanicznych istniejącego ustroju przy stosunkowo niskich kosztach materiałowo-wykonawczych - 2 i 3-krotnie niższych od pozostałych analizowanych rozwiązań. Na wybór rozwiązania, oprócz aspektu ekonomicznego, wpływ miały także inne czynniki takie jak łatwość technologii wykonania, sztywność ustroju oraz bardzo korzystna ostateczna wysokość stropu umożliwiająca uzyskanie największej powierzchni użytkowej. Bardzo istotna była również możliwa do osiągnięcia wielkość balkonu $(11$ x 1,9 m).

$\mathrm{W}$ przedstawianych adaptacjach kamienic $\mathrm{w}$ zasadzie tylko strop przy ul. Kraszewskiego 1 dawał szansę bezpośredniego wykorzystania. Nad ostatnią kondygnacją w tym budynku został zastosowany strop gęstożebrowy prefabrykowany DMS. Ekspertyza konstrukcyjna wykonana na podstawie dokumentacji archiwalnej i odkrywek wykazała brak odpowiedniej nośności dla adaptacji na obciążenia użytkowe funkcji mieszkalnej. Przeprojektowano jednak układ 
warstw wykończeniowych istniejącego stropu co pozwoliło na jego bezpośrednie wykorzystanie. Usunięto polepę z warstwami wylewek cementowych i ocieplenia zastępując je podłogą pływającą z izolacją akustyczną. Zmniejszone zostały w ten sposób obciążenia na jego konstrukcję i korzystnie obniżono jej wysokość.

\subsection{Więźba}

Podobnie jak ze stropami okazuje się przedstawiać sytuacja z więźbą dachową. Rzadko kiedy możliwe jest wykorzystanie istniejącej konstrukcji bez konieczności dokonania wzmocnień czy wymiany jej elementów. Więźby projektowane kilkadziesiąt lat temu z reguły nie spełniają wymagań współczesnych norm. O ile więźby te lepiej lub gorzej funkcjonują w przestrzeni strychu jako np. nieocieplonej suszarni, to w przypadku zmiany przeznaczenia na cele mieszkalne przekroje elementów nośnych konstrukcji dachu muszą zapewnić przeniesienie dodatkowych obciążeń $\mathrm{z}$ nowych warstw wykończeniowych i muszą ponadto spełniać obecne normy. $\mathrm{W}$ omawianych kamienicach niemal w całości wymieniono konstrukcje więźb w przestrzeniach objętych zmianą sposobu użytkowania. Powody tego były różne.

W kamienicy przy ul. Grodzisko 3 ekspertyza mykologiczno-konstrukcyjna wykazała zły stan niemal wszystkich elementów nośnych więźby - murłaty, płatwie, słupki, kleszcze zostały porażone przez owady Spuszczela i Kołatka, grzyb wroślak rzędowy, a miejscowo, zwłaszcza w styku z murem nasiąkniętym wilgocią, także spróchniałe. Stwierdzono także znaczne ugięcia krokwi i za małe przekroje w stosunku do długości elementów; wątpliwości budziła też jakość zastosowanego drewna. W części południowej wymiana wskazana była nadto ze względu na zmianę nachylenia połaci dachu (poprzez wstawienie lukarny pulpitowej) konieczną dla wytworzenia przestrzeni użytkowej tej niskiej części strychu.

W przypadku więźby dachu budynku przy ul. Kraszewskiego 1 powodem korekty więźby była konieczność dostosowania jej układu do potrzeb funkcjonalnych. Pochyłe stolce, przenoszące obciążenia z płatwi pośrednich na nośną ścianę podłużną biegnącą $\mathrm{w}$ środku budynku, tworzyły wprawdzie interesującą konstrukcję, ale jej walory wizualne kolidowały z optymalnym zakomponowaniem powierzchni strychowej. Eliminacja słupów drewnianych i wprowadzenie ramy stalowej pozwoliły tutaj na wytworzenie antresoli i dodatkowej powierzchni użytkowej w przekształcanym poddaszu. Lukarny, które często dopuszczane są jako mniej agresywna alternatywa dla całkowitej zmiany formy dachu są kolejnym czynnikiem powodującym ingerencję $\mathrm{w}$ strukturę więźby. W adaptacji przy ul. Kraszewskiego dzięki dużym lukarnom pulpitowym udało się osiągnąć przestronną, niemal w pełni użytkową powierzchnię mieszkalną. Wykorzystano także przestrzeń nad klatką schodową, której powierzchnię włączono do antresoli mieszkań. W trakcie budowy, decyzją Inwestora zrezygno- 
wano z podziału i nastąpiło scalenie obydwu lokali. W ramach zmiany projektu budowlanego doprojektowano kolejne dwie lukarny w przestrzeni antresoli znacznie poprawiając jej parametry przestrzenne.

W kamienicach mieszczańskich z końca XIX i początków XX wieku, stosowano w układach więźb dachowych konstrukcje niezależne od konstrukcji stropowych. Dolne belki tych wiązań przenoszące siły rozporowe (tramy) ze względu na ich dużą wysokość i znaczne wyniesienie są elementami, które mogą dostarczać wiele problemów przy rozwiązywaniu układów mieszkań w przestrzeni strychowej. Sytuacja taka ma miejsce w kamienicy przy pl. Śreniawitów. Ograniczona wysokość przestrzeni strychu nie sprzyja wprowadzeniu konstrukcji podłogi w górnej płaszczyźnie tramów. Przebieg tramów wyklucza możliwość wkomponowania ich w układ funkcjonalny. Dlatego w porozumieniu z Konserwatorem zabytków założono przebudowę więźby z założeniem likwidacji kolidujących belek.

\subsection{Kominy i instalacje}

Większość kamienic wznoszonych w pierwszej połowie XX w. i wcześniej ogrzewana była przez piece na paliwo stałe podpięte do przewodów dymowych, które wobec następujących z czasem zmian w sposobie ogrzewania budynku, straciły swą przydatność. Zmieniły się również zasady wentylacji z bezpośredniej na pośrednią, dzięki czemu istnieje pewna ilość "wolnych" nie używanych przewodów kominowych. Część z nich można rozebrać, zaś część przewodów w przypadku kolizji z projektowaną funkcją może być przebudowana, większość jednak stanowi trwały komponent rozwiązywania układu funkcjonalnego stanowiąc swoisty szkielet dla projektowanej funkcji.

W adaptacjach przy ul. Grodzisko i pl. Śreniawitów stosowano zarówno rozbiórkę części przewodów jak i przebudowę układu wentylacji na wysokości strychu, dzięki czemu uzyskano zwiększenie powierzchni użytkowej, ale przede wszystkim większą swobodę uzyskania prawidłowego rozwiązania układu funkcjonalnego.

W kamienicy przy ul. Grodzisko podjęto też próbę wykorzystania istniejącego nie używanego przewodu kominowego do wprowadzenia nowego pionu kanalizacji sanitarnej. Niestety pomimo pozytywnej opinii kominiarskiej w zakresie drożności przewodu, na etapie realizacji inwestycji, z powodu nie prostoliniowego przebiegu przewodu, nie powidło się wprowadzenie do niego rury kanalizacji sanitarnej. W konsekwencji zmusiło to Inwestora do przebudowy istniejącego w pobliżu pionu ks, tak żeby można było przypiąć do niego kolejne przybory. 


\section{Uwagi końcowe}

Złożoność inwestycji związanej ze zmianą sposobu użytkowania strychu ujawnia się również na etapie realizacji prac budowlanych. Nieodłączne podczas budowy hałas, pylenie i uszkodzenia, możliwości zalania pomieszczeń na niższych kondygnacjach są bardzo uciążliwe dla aktualnych użytkowników budynku. Często występują sytuacje braku zrozumienia i cierpliwości z ich strony dla uwarunkowań związanych z prowadzeniem prac. Dlatego w przypadku prowadzenia inwestycji w czasie normalnej eksploatacji budynku istotne jest przyjmowane rozwiązań projektowych umożliwiających szybki postęp prac, minimalizujących potencjalne uciążliwości i zagrożenia dla otoczenia inwestycji, z unikaniem w miarę możliwości ciężkich technologii budowlanych.

\section{Literatura}

[1] Pełczyński J., Tomkowicz B.: Zagadnienia etapu wstępnego zmiany sposobu użytkowania strychów w strefie śródmiejskiej na cele mieszkalne na przykładzie wybranych kamienic w Rzeszowie, Czasopismo Inżynierii Lądowej, Środowiska i Architektury - Journal of Civil Engineering, Environment and Architecture, JCEEA, t. XXXI, z. 61 (3/II/14), 2014, s. 411-422, DOI:10.7862/rb.2014.107.

[2] Frodl W.: Pojęcie i kryteria wartościowania zabytków, Wyd. ODZ, Warszawa 1966.

[3] Tomkowicz B., Pełczyński J.: Problemy modernizacji obiektów położonych w strefie ochrony konserwatorskiej na przykładzie przebudowy budynku mieszkalnego przy ul. Piekarskiej 13 w Kolbuszowej, Zeszyty Naukowe Politechniki Rzeszowskiej, 2012, z. 59, tom II, nr 2, s. 777-789.

[4] Motak E., Zapał L.: Wybrane zagadnienia konstrukcyjne adaptacji poddaszy budynków zabytkowych, materiały konferencyjne w książce V konferencja naukowotechniczna REW-INŻ’2000 Kraków, T.2, Wyd. Politechniki Krakowskiej, s.163-170.

[5] Borzym K., Węgrzynowski W.: Ocena możliwości przebudowy poddaszy i nadbudowy budynków, Materiały Budowlane, wyd. SIGMA-NOT, 11/1999, s. 5-9.

[6] Thierry J.: Remonty budynków i wzmacnianie konstrukcji, Wyd. Arkady, Warszawa 1982.

[7] Masłowski E., Spiżewska D.: Wzmacnianie konstrukcji budowlanych, Wyd. Arkady, Warszawa 2000.

\section{ISSUES OF DESIGN PHASE THE LOFT CONVERSION IN DOWNTOWN BY EXAMPLES OF SELECTED TENEMENTS IN RZESZÓW}

\section{S u m m a r y}

One of obtaining ways of usable areas in city centers is an adaptation of attics of buildings. Interest is the ability to produce housing a unique, individual character at relatively low cost. Lofts adaptation in the downtown area can be treated as well as action in the framework of sustainable development, opposed to the trend of urban sprawl. Numerous benefits of such action appear both in the building and the city. In practice, the process of acquisition and conversion of loft on the 
apartment can be a long and complex, as at the formal as the design level. Existing conditions of design can be divided into several major groups, including: the technical condition of the building, the formal and legal level, considerations of architecture, construction, and plants . Full study of the existing conditions in the predesign stage is an essential foundation for an optimal designation of assumptions the adaptation. The article discusses of issues the design phase on three examples of adaptation four-storey tenement houses in Rzeszów, which differ in terms of monuments conservation requirements: the building at 1 Kraszewski Street lying in the zone of protection and conservation, the building at 2 Śreniawitów Square entered in the municipal files of monuments and building at 3 Grodzisko Street entered in the register of monuments. The article presents the general design considerations related to the change of using, assumptions and solutions to adapt these lofts in the field of function, ceilings and roof truss.

Keywords: adaptation, reconstruction, change of function, the conditions of adaptation design

DOI:10.7862/rb.2016.285

Przestano do redakcji: $30.11 .2016 r$.

Przyjęto do druku: 20.12.2016 r. 